(vol. $33 \mathrm{ff}$.) Isis will be printed in the United States. The first American number will include a list of all the papers and reviews which were to have appeared in No. 84 and vol. 32. Isis as prepared in America will probably be smaller than that of its Belgian predecessor, but the editorial policy will remain essentially the same. As regards Osiris, which was founded in 1936 in order to relieve Isis of the longer papers, it is not supported by the History of Science Society, and hence subscriptions to it or correspondence relative to it should not be addressed to the Secretary of the Society, but to Dr. Alexander Pogo (Harvard Library, 189, Cambridge, Mass.). At the time of the German invasion of Belgium, two volumes of Osiris were being printed, namely, vol. 8, dedicated to Paul Ver Eecke, historian of Greek mathematics, and vol. 9, dedicated to Max Meyerhof, historian of Arabian medicine. These two volumes will appear in due course. Vol. 7 is reviewed on p. 247 of this issue of Nature.

\section{July Earthquakes Registered at Kew}

DURING July 1940 ten strong earthquakes were registered at Kew. Most of these were at a considerable distance, and five gave ground movement at Kew of greater amplitude than $10 \mu$. The greatest was on July 30 , registered at $17 \mathrm{~m} .49 \mathrm{~s}$. past midnight G.M.T., which gave an amplitude of $45 \mu$ at Kew. This shock had an epicentre some $3,020 \mathrm{~km}$. distant from Kew and was the earthquake near Yozgad in Turkey (Nature, August 10, p. 196). The earthquake with the greatest depth of focus which occurred during the month was on July 10, with a provisionally estimated depth of $600 \mathrm{~km}$.

\section{Scholarships in Agriculture}

ON the recommendation of the Agricultural Research Council, the following awards have been made by the Ministry of Agriculture and Fisheries and the Department of Agriculture for Scotland: Ivor Isaac, University College, Swansea, a threeyear research scholarship in plant pathology; J. S. Perry, University College of North Wales, Bangor, a three-year research scholarship in zoology; D. McFarlane, Glasgow Veterinary College and University of Glasgow, a studentship for research in animal health.

\section{Awards in Engineering}

THE following scholarships for 1940 have been awarded by the Institution of Electrical Engineers : Duddell Scholarship, annual value $£ 150$, tenable for 3 years, to D. LaW. W. King (Northampton Polytechnic); Silvanus Thompson Scholarship, annual value $£ 100$, plus tuition fees, tenable for 2 years, 1938 award to H. Darnell (University of Liverpool) renewed for a third year, no new award made this year; William Beedie Esson Scholarship, annual value $£ 100$, plus tuition fees, tenable for 2 years, renewable in approved cases for a third year, C. $H$. Bickerdike (London and North Eastern Railway Co.); David Hughes Scholarship, value $£ 100$, tenable for 1 year, J. H. Nicoll (Merchant Venturers' Technical College, Bristol); Salomons Scholarships, value
$£ 60$, tenable for 1 year, H. H. Rosenbrock (University College, London); value $£ 40$, tenable for 1 year, P. H. W. Whyman (University College, London); Thorrowgood Scholarships, annual value $£ 1210 s$. each, tenable for 2 years, R. J. Post (London Passenger Transport Board), R. P. Gasson (Southern Railway Co.). No award of the Ferranti or Swan Memorial Scholarships or of grants from the War Thanksgiving Education and Research Fund have been made this year.

The following awards have been made by the North East Coast Institution of Engineers and Shipbuilders: Institution Scholarship $(£ 100)$ to Ian Welsh Goodlet, an apprentice of Messrs. R. \& W. Hawthorn, Leslie \& Co., Ltd., St. Peter's Works, Newcastle-onTyne; bursary of $£ 50$ to Eric William Simpson, an apprentice of Messrs. A. Reyrolle \& Co., Ltd., Hebburn-on-Tyne; M. C. James Medal to Mr. H. J. Tapsell, of the National Physical Laboratory, for his paper on "Creep at High Temperatures"; Thomas Fenwick Reed Medal to Mr. Harry Chilton, now at sea, previously with North Eastern Marine Engineering Co. (1938) Ltd., Sunderland (awarded biennially in recognition of evidence of ability to take a share in the control of industry); R. L. Weighton Medal to Wilfred Bailey, on the result of the Durham final engineering degree examination at King's College, Newcastle-upon-Tyne.

\section{Announcements}

THE title of professor of physics applied to medicine in the University of London, with the status and designation of appointed teacher, has been conferred on Dr. W. V. Mayneord in respect of the post held by him at the Royal Cancer Hospital (Free).

Prof. H. Vincent, professor of epidemiology in the Collège de France, formerly inspector-general of the Health Service of the French Army, has been elected vice-president of the Paris Academy of Sciences.

DR. H. MARk, formerly professor of physical chemistry in the University of Vienna, has been appointed professor of organic chemistry in the Polytechnic Institute of Brooklyn. He will direct research in the field of high molecular weight compounds.

AT a meeting of the Society of Experimental Psychology recently held at the University of Pennsylvania, the Howard Crosby Warren Medal, which is given annually by the Society for outstanding research in the field of experimental psychology, was awarded to Ernest R. Hilgard of Stanford University, for his analysis of the conditioned response and his demonstration of its integration with the verbal and volitional processes in learning and retention.

By acquiring the 335,000 Jews of the Baltic States the Soviet Union now has the largest Jewish population in the world, 4,835,000, made up approximately as follows : Russia proper, 3,050,000 ; Soviet Poland, 1,250,000; Bessarabia, 200,000; Baltic States, 335,000 . 